\title{
Gagasan Democratic Peace \\ Dalam Politik Luar Negeri Amerika Serikat
}

\author{
Rizki Dian Nursita \\ Universitas Muhammadiyah Yogyakarta \\ rdiannursita@gmail.com

\section{Surwandono} \\ Universitas Muhammadiyah Yogyakarta \\ wsurwandono@yahoo.com
}

\begin{abstract}
Abstrak
Tulisan ini menganalisa tentang pengaruh gagasan dalam Democratice Peace Theory terhadap politik luar negeri Amerika Serikat dengan menggunakan metode library research. Tulisan ini menemukan bahwa democratic peace secara jelas telah menggerakkan politik luar negeri Amerika Serikat pada era Bill Clinton dan George W. Bush. Pada era Obama, sentuhan akan democratic peace juga memengaruhi politik luar negerinya. Politik luar negeri Amerika Serikat saat ini di bawah kepemimpinan Trump lebih dipengaruhi oleh gagasan nasionalisme dibandingkan dengan ide-ide demokratisasi.
\end{abstract}

Kata kunci : America Serikat, Democratic Peace Theory, Politik Luar Negeri

\section{Pendahuluan}

Democratic peace theory merupakan salah satu teori yang cukup mengenai interaksi antaraktor, atau dalam hal ini negara yang masyhur dalam hubungan internasional, terutama bagi pendekatan liberalisme. Gagasan liberalisme tentang keadilan, order, kebebasan, dan norma telah menghadirkan sentuhan yang berbeda dibandingkan dengan pandangan realis selalu diidentikkan dengan konflik, perang, dan struktur yang anarki.

Salah satu pemikir liberalis klasik; atau lebih tepatnya idealis, dalam hubungan internasional, Immanuel Kant memandang bahwa arena dalam hubungan internasional 
sebagai "lawless state of savagery", atau kondisi yang tidak bermoral dan penuh dengan kebiadaban(Dunne, 2005). Kant dalam bukunya 'Perpetual Peace', mengungkapkan bahwa, hanya liberalismelah yang dapat menciptakan perdamaian antarnegara, karena negara liberal cenderung 'pasifis' dengan sesama negara liberal. Tesis Kant mengenai perdamaian inilah yang kemudian memotivasi sejumlah "Kantian" dalam ilmu hubungan internasional. Hingga akhirnya democratic peace theory pun terlahir.

Kita bisa melihat bagaimana gagasan dalam democratic peace theory memengaruhi politik luar negeri Amerika Serikat. Seperti dalam kebijakan Bill Clinton yang mendukung demokratisasi di negara-negara pecahan Uni Soviet pada tahun 1994, atau demokratisasi yang menjadi justifikasi bagi penerus Clinton, George W. Bush untuk melawan rezim otoriter di Timur Tengah pada tahun 2003. Bahkan di era Obama, Amerika Serikat juga mengutuk pemerintahan yang otoriter, seperti di Libya dan Suriah. Lantas, bagaimanakah dengan kebijakan luar negeri Donald Trump yang dikenal dengan "America First Foreign Policy"? Apakah hal tersebut juga dipengaruhi oleh gagasan dalam democratic peace theory sebagaimana pendahulunya? Tulisan ini mencoba untuk menjawab pertanyaan tersebut.

\section{Akar dan Gagasan Utama Democ- ratic Peace}

Salah satu ilmuwan liberalis klasik yang mengkritik tentang praktik hubungan internasional yang dipenuhi dengan kekerasan, serta perilaku yang barbar adalah Immanuel Kant. Walaupun telah ditulis sejak dua abad silam, namun gagasan Immanuel Kant tentang perdamaian dalam tesisnya yang berjudul Perpetual Peace dianggap sebagai benih bagi sejumlah gagasan dalam liberalisme. Dalam tulisannya, Kant menjelaskan bahwa kondisi dunia bisa bertransformasi menjadi damai, bahkan perdamaian yang abadi bisa tercapai karena adanya kesadaran pada tiap individu tentang perdamaian, konstitusi yang republik, serta kontrak antarnegara untuk menyudahi perang, dan kosmopolitanisme atau komunitas universal(Dunne, 2005).

Persatuan negara-negara yang terikat dalam perjanjian internasional lebih efektif untuk menciptakan perdamaian dibandingkan dengan adanya institusi suprastate atau pemerintahan dunia yang mengawasi perdamaian antarnegara. Kant mengklaim bahwa 
negara yang liberal akan cenderung pasifis dalam hubungan internasional dengan sesama negara liberal. Negara liberal juga dianggap tend to be wealthy; cenderung lebih makmur apabila dibandingkan dengan negara yang menganut sistem otoritarian. Gagasan Kant kemudian 'bangkit' pada tahun 1980-an. Gagasan tersebut cukup memengaruhi sejumlah pakar hubungan internasional yang kemudian dikenal dengan Kantian.

Michael Doyle misalnya, menyampaikan bahwa negaranegara liberal telah membentuk perdamaian yang terpisah, atau separate-peace satu sama lainnya. Negara-negara demokrasi mungkin tidak sepenuhnya terlepas dari konflik, maka dari itu Doyle membagi negara-negara demokrasi menjadi peace-prone, dan warprone(Doyle, 1986). Yaitu negaranegara yang memiliki kecenderungan untuk 'damai', serta kecenderungan untuk 'berperang'. Tanpa adanya pemerintahan yang demokratis, komitmen terhadap pemikiran untuk menjaga hak asasi manusia, serta kesaling ketergantungan transnasional, maka suatu negara dikategorikan sebagai war-prone(Richardson, 2012).

Democratic peace menjadi teori bagi pendekatan liberal mengenai isu keamanan internasional, terutama bagi sejumlah fenomena yang terjadi pasca-Perang Dingin. Bagi para penggagas democratic peace, demokrasi akan menciptakan perdamaian bagi sesama negara yang demokratis, perang dan kekerasan antarnegara demokratis dapat diminimalisir, atau bahkan tidak terjadi. Negara-negara yang demokratis akan menghadapi kompetisi terkait dengan kepentingan nasionalnya. Namun, kompetisi tersebut melibatkan kekerasan dan penyelesaian melalui militer, seperti yang dilakukan oleh negara-negara non-demokratis. Hal tersebut dikarenakan negaranegara demokratis terikat oleh nilai-nilai, serta keterikatan dalam institusi internasional. Dalam kompetisi tersebut, negara-negara yang demokratis akan cenderung menggunakan jalan non militer untuk mencapai kepentingannya, atau ketidaksetujuannya, seperti melalui jalan mediasi, negosiasi, serta diplomasi(Baylis, 2005).

Walaupun demikian, korelasi antara demokrasi dengan perdamaian masih terus menjadi perdebatan dalam diskursus hubungan internasional. Democratic peace sering menuai kritik baik secara teoritis, maupun praktis. Apakah hubungan antara 
demokrasi dengan perdamaian adalah hubungan kausalitas atau tidak. Ataukah terdapat faktor lain di samping demokrasi yang menyebabkan hubungan antara negara demokratis? Perdamaian yang terjadi di antara negaranegara di Uni Eropa, khususnya Eropa Barat, menurut Cohen bukan semata-mata dikarenakan demokrasi, namun karena adanya kesamaan pengalaman sejarah serta kultur (Pugh, 2005). Kita juga dapat menyaksikan bagaimana hubungan 'dekat' antara Amerika Serikat dengan negara non-demokratis, seperti Arab Saudi yang menganut sistem monarki merupakan suatu anomali.

\section{Democratic Peace dalam Politik Luar Negeri Amerika Serikat}

Teori Democratic Peace terkadang dipandang sebagai bentuk 'dalil' oleh pemerintah Amerika Serikat dalam menjalankan politik luar negerinya. Amerika Serikat, negara yang dikenal sebagai promotor demokrasi, bahkan sejak era Perang Dingin.Pasca-Perang Dingin, tepatnya pada Era Presiden Bill Clinton pada tahun 1994, Presiden Clintonyang berasal dari Partai Demokrat, menggunakan demokrasi sebagai alasan bagi politik luar negeri Amerika Serikat untuk mendukung serta mempromosikan demokratisasi kepada negara-negara di Eropa Timur, atau negara-negara bekas Uni Soviet. Setelah Yugoslavia mengumumkan kemerdekaannya pada tahun 1992, konflik pun terjadi di BosniaHerzegovina, antara Serbia dengan Bosniaks (Muslim), dan Kroasia.

Pada awalnya Clinton meminta kepada negara-negara di Eropa Barat untuk mengambil tindakan terhadap orang-orang Serbia yang terus melakukan agresi terhadap Bosniak dan Kroasia. Namun, ketika orang-orang Serbia hampir menguasai Bosnia dan Kroasia pada bulan November, Clinton membanting setir dengan mendorong konsiliasi dengan orangorang Serbia. Pada bulan November 1995, pemerintahan Clinton mengadakan pembicaraan damai antara pihak-pihak yang bertikai di Bosnia. Dari upaya konsiliasi tersebut kemudian lahirlah sebuah kesepakatan damai yang dikenal dengan Dayton Accords. Bosnia kemudian menjadi negara tunggal yang terdiri dari dua entitas terpisah dengan pemerintah pusat(Dumas, 2009).

Tidak hanya Presiden Bill Clinton, Presiden George W. Bush, yang menggantikan Bill Clinton, juga menggunakan democratic 
peace untuk menjustifikasi apa yang kemudian dikenal dengan Bush Doctrine.Bush Doctrine adalah doktrin yang dikeluarkan oleh Bush pasca-peristiwa pemboman WTC pada 11 September 2001. Doktrin tersebut secara garis besar berisi gagasan Bush mengenai perang melawan terorisme, demokratisasi, national security, dan justifikasi terhadap pre-emptive war; atau pencegahan terhadap ancaman dari musuh dengan menyerang terlebih dahulu. Doktrin tersebut merupakan ciri khas dari pemikiran Partai Republik, yang banyak dipengaruhi oleh ideologi neoconservatismyang sangat kental akan realisme politik.

Presiden Bush secara terbuka mengancam akan memerangi terorisme dan melakukan propaganda terhadap gerakan antiterorisme kepada dunia. Bush membentuk koalisi anti-terorisme pada tahun 2001 dengan mengirimkan pasukan ke Afghanistan. Bush juga menegaskan bahwa rezim Saddam Hussein di Irak merupakan ancaman serius bagi keamanan Amerika Serikat. Saddam Hussein diduga memiliki senjata pemusnah massal yang dikaitkan dengan gerakan terorisme internasional. Amerika Serikat kemudian melakukan agresi militer di Irak pada tahun 2003(Cole, 2008). Agresi ini kemudian mengakhiri rezim Saddam Hussein di Irak.

Bush menyampaikan gagasan democratic peace kepada publik dalam konferensi pers pada tahun 2004. Dalam pidatonya, Bush menjelaskan bahwa alasan Bush untuk menegakkan demokrasi dengan 'tegas', adalah karena negara-negara yang mengusung demokrasi tidak akan berperang satu dengan yang lainnya. Rakyat yang berada di negara demorkatis tidak berperang, karena mereka tidak menyukainya, dan mereka mengerti tentang konsekuensi dari perang. Melalui usaha partai neokonservatif, democratic peace theory telah bertransformasi menjadi keyakinan politik, sehingga situasi menjadi sangat kondusif bagi Bush untuk mengampanyekan dan melegetimasi Bush Doctrine(IshShalom, 2013).

Terdapat tiga alasan bagi kelompok neo-konservatif di Amerika Serikat dalam mempromosikan demokrasi. Pertama, penyebaran demokrasi akan memperluas zona perdamaian dan mengatasi ancaman terhadap peradaban, terorisme global dan sejumlah negara yang berbahaya. Kedua, negara dapat dikatakan demokratis secara struktur, bukan 
hanya sekadar kultur. Ketiga, struktur demokrasi juga dapat diterapkan di negara-negara yang memiliki peradaban serta kultur yang berbeda dengan negara-negara demokratis di Barat. Tiga alasan tersebut menjelaskan mengapa neokoservatif menjadi promotor bagi demokratisasi di dunia, terutama di negara-negara di Timur Tengah. Bahkan hal ini juga melegitimasi penggunaan militer apabila diperlukan (Ish-Shalom, 2013). Gagasan democratic peace pada era Bush kemudian menjadi ciri khas, serta agenda besar bagi neo-konservatif untuk mempromosikan demokrasi.

Berbeda dengan kedua pendahulunya, kebijakan luar negeri Amerika Serikat era Barack Obama tidak dipengaruhi oleh gagasan dalam democratic peace dan upaya demokratisasi. Bagi Obama, penggunaan militer secara unilateral hanya akan dilakukan apabila terdapat ancaman langsung terhadap kepentingan Amerika Serikat; berbeda dengan konsep pre-emptive war yang diberlakukan pada era Bush. Sedangkan kekuatan militer multilateral akan digunakan apabila terdapat ancaman tidak langsung yang mengganggu kelompok yang tertindas. Terkait dengan keamanan, Obama juga memasukkan perlawanan terhadap proliferasi senjata pemusnah massal, serta pencegahan genosida dalam politik luar negerinya.

Obamajuga tidakmenggunakan diktum "Global War on Terrorism", meminta penutupan fasilitas penahanan di Guantanamo, berjanji untuk menarik pasukan dari Irak dan Afghanistan, serta rekonsiliasi dengan Rusia dengan mengabaikan program rudal anti-balistik di Polandia, Ceko, dan Afghanistan. Obama juga berupaya melakukan sejumlah pendekatan dengan negara-negara di Asia, termasuk China. Walaupun tidak secara eksplisit menggunakan gagasan demokratisasi dalam politik luar negerinya, namun kita tidak dapat mengabaikan intervensi Amerika Serikat di bawah pemerintahan Obama dalam perang sipil di Libya dan Suriah. Baik Ghadafi dan Assad, keduanya adalah pemimpin 'otoriter' dan telah berkuasa cukup lama. Bagaimanapun, kita masih dapat melihat sentuhan democratic peace dalam politik luar negeri Obama.

\section{Donald Trump dan America First Foreign Policy}

Setelah Donald Trump terpilih menjadi presiden, pada tanggal 27 April 2017, Trump menyampaikan visi dari kebijakan luar negerinya 
yang kemudian diberi nama sebagai "America First"(Wąsiński, 2017). Doktrin 'America First' tentu saja menjadi sorotan tidak hanya pada tataran domestik, namun juga menyita perhatian internasional. America First merupakan implementasi dari slogan Trump "Make America Great Again!” selama kampanye pilpres. Banyak masyarakat dan pakar politik yang mengira bahwa Amerika Serikat di bawah Trump akan memberlakukan politik isolasionis lewat America First. "America First" sendiri identik dengan politik isolasionis Amerika Serikat pada Perang Dunia II yang dikeluarkan oleh America First Committee, sebelum akhirnya Amerika Serikat masuk ke dalam konstelasi Perang Dunia pasca-hancurnya Pearl Harbour pada tahun 1941. Walaupun pada akhirnya dugaan tersebut tidak sepenuhnya benar, karena memberantas Islamic State of Iraq and Syria (ISIS) juga merupakan salah satu kebijakan luar negeri Trump .

Sebagai presiden yang berasal dari Partai Republik, seperti halnya Bush, kebijakan Trump tentunya juga dipengaruhi oleh pemikiran neo-konservatif. Dalam website resmi White House, tertulis bahwa America First bertujuan untuk menciptakan dunia yang damai, walaupun menggunakan pendekatan yang militeristik, "Peace through strength will be at the center of that foreign policy"(White House, 2017). Di samping keamanan, kebijakan luar negeri Trump juga concern perihal ekonomi serta kerjasama luar negeri. Walaupun sama-sama berasal dari Partai Republik, lantas apakah America First adalah reinkarnasi dari Bush Doctrine yang memuat gagasan demokratisasi?

Isu tentang terorisme dan Islam radikal sejatinya bukanlah hal yang baru bagi Amerika Serikat pascaperistiwa WTC 9/11. Sebelum Trump terpilih menjadi presiden, dalam kampanyenya ia selalu mempromosikan perlawanan terhadap kelompok Islamic State of Iraq and Syria/ Levant atau yang dikenal dengan ISIS/ISIL atau Daesh. Seperti yang tertulis dalam website White House, perlawanan terhadap kelompok ISIS ini bahkan ditempatkan sebagai "highest priority" bagi Amerika Serikat(White House, 2017). Dalam hal ini, Trump berupaya untuk membuat koalisi dan kerjasama militer yang agresif dan berupaya untuk mengajak negara lainnya untuk menghentikan suport dana bagi kelompok teroris, saling berbagi informasi, serta menggalakkan 
perlawanan terhadap terorisme. Di samping itu, Trump juga merencanakan untuk membuka kembali aliansi militer Amerika Serikat dalam NATO.

Pada tanggal 13 April 2017, militer Amerika Serikat menyerang kelompok teroris dengan menjatuhkan MOAB di Afghanistan; Massive Ordnance Air Blastyang merupakan bom non-nuklir terkuat yang juga dikenal dengan "Mother of All Bombs". Sebagian besar memberikan applause terhadap serangan tersebut, namun yang mengutuk serangan tersebut juga tidak sedikit.Walaupun demikian, kita masih belum memastikan motivasi Trump dalam serangan tersebut, karena hal tersebut bukanlah tindakan pre-emptive war seperti halnya yang disuarakan oleh Bush untuk menjustifikasi agresi Amerika Serikat terhadap Irak, dan Amerika Serikat juga kini tidak mendapatkan ancaman langsung seperti peristiwa 9/11.

Tidak hanya itu, Trump berupaya untuk mendekati Rusia dalam rangka mengajak kerja sama dalam memberantas terorisme di Suriah. Padahal selama kepemimpinan Obama, Rusia selalu mendukung dan berada di balik rezim Assad yang otoriter, sedangkan Obama menentangnya. Bahkan selama kampanye, sempat muncul kecurigaan dari kubu Clinton mengenai keterlibatan Putin dalam pemilu di Amerika Serikat. Hubungan antara Trump dengan Putin semakin membaik, Trump bahkan dalam akun sosial media pribadinya menyebut Putin sebagai orang yang "cerdas".

Tidak hanya propaganda antiterorisme, propaganda anti-komunisme pun juga menjadi hal yang mencolok dalam empat bulan kepemimpinan Trump. Konfrontasi antara Amerika Serikat dengan Korea Utara pun kembali muncul ke permukaan di bawah administrasi Trump. Uniknya, Trump juga mengajak China yang juga komunis, untuk sama-sama menjadikan Korea Utara yang menganut Juche dan komunisme sebagai ancaman. Pesan-pesan anti-terorisme dan anti-komunisme (Korea Utara) disampaikan oleh Trump dengan penekanan "unilateralisme" Amerika Serikat apabila negara lain tidak mau bekerjasama.

Di samping persoalan keamanan, Trump juga mengajak China untuk bekerjasama dalam bidang ekonomi. Amerika Serikat kini melihat China bukan sematamata sebagai pesaing. Namun, kemajuan perekonomian China yang begitu pesat dalam beberapa tahun 
ini, serta downturn yang dialami oleh Amerika Serikat, menyebabkan Amerika juga memiliki kepentingan terhadap China. Pendekatan terhadap China dilakukan Trump dengan mengundang Presiden China, Xi Jinping untuk dalam sebuah negosiasi yang diadakan di kediaman Trump pada 06 April 2017. Tidak hanya itu, Trump juga menyampaikan dukungannya terhadap One-China Policy. Padahal, Taiwan merupakan kawasanyang demokratis, dan Taiwan juga memberikan ucapan selamat tepat setelah Trump terpilih menjadi presiden.

Isu migrasi juga menjadi security concern dalam politik luar negeri Trump. Problem migran serta lapangan kerja menurutnya merupakan persoalan mendasar yang harus segera dituntaskan. Amerika Serikat selama ini merupakan rumah bagi migran dari 60 negara. Tingginya tingkat migran di Amerika Serikat bagi neo-konservatif sering dikaitkan dengan ancaman keamanan (terorisme) serta penyebab melemahnya perekonomian Amerika serta meningkatnya jumlah pengangguran. Dalam pidato Trump pada tanggal 15 Agustus 2016, Trump menyebutkan sejarah serangan terorisme di Amerika Serikat yang telah lalu; 9/11, penembakan di Fort
Hood, bom Marathon di Boston, penembakan di Chattanooga, Tennessee; the Orlando Nightclub, sebagai justifikasi kebijakan Trump untuk memberlakukan travel ban terhadap migran dari negara-negara yang memiliki keterkaitan sejarah dengan terorisme(Politico Staff, 2016).

Maka dari itu, pada tanggal 27 Januari 2017, Trump menandatangani kebijakan untuk menangguhkan para migran yang berasal dari sejumlah negara Islam, seperti Irak, Iran, Libya, Somalia, Sudan, Syria, dan Yaman selama 120 hari, karena dikhawatirkan kedatangan mereka akan membawa ancaman bagi keamanan nasional Amerika Serikat. Kebijakan ini kemudian direvisi pada Maret 2017 dengan mengecualikan Irak (Chakraborty, 2017).Tidak sampai disini, Trump kerap kali menekankan bahwa Amerika harus membangun tembok yang membatasi Amerika dengan Meksiko untuk menghalangi arus migran. Bahkan Trump juga menyampaikan bahwa Meksiko adalah negara yang penuh dengan masalah, seperti cartel dan perdagangan obat bius, pemerkosaan, dsb. Retorika Trump sebagai kandidat dan kini sebagai presiden nampaknya "menghidupkan ketegangan hubungan antara 
Amerika Serikat-Meksiko yang tidak terlihat dalam beberapa dasawarsa"(Gaouette \& Kosinski, 2017).

Keluarnya Amerika Serikat dari Trans-Pacific Partnership(TPP) merupakan kebijakan ekonomi pertama yang dilakukan oleh pemerintahan Trump, pasca-terpilihnya Trump menjadi presiden. Padahal TPP semestinya bisa menjadi wadah bagi Amerika Serikat untuk membangun hubungan dengan sejumlah negara di Asia, serta mempromosikan demokrasi. Trump juga akan memberlakukan impor pajak bagi perusahaanperusahaan Amerika Serikat yang memindahkan operasinya ke Meksiko dan menyampaikan bahwa Amerika akan keluar dari WTO apabila impor pajak tersebut tidak dapat tercapai (Needham, 2016). Trump juga akan mengupayakan renegosiasi NAFTA, dengan menekankan bahwa Amerika juga akan keluar dari keanggotaan NAFTA apabila tidak terjadi renegosiasi. "If our partners refuse a renegotiation that gives American workers a fair deal, then the President will give notice of the United States' intent to withdraw from NAFTA" (White House, 2017). Amerika Serikat kini melihat bahwa kerjasama internasional terkadang menjadi burden bagi perekonomian nasional.

\section{Kesimpulan}

Democratic peace adalah teori yang cukup 'tua' dalam hubungan internasional. Kelahiran democratic peace sendiri merupakanmanifestasi dari kekecewaan Kant dalam melihat kondisi di Eropa yang pada saat itu 'memperihatinkan'. Idealisme Kant kemudian dikembangkan oleh Doyle, Doyle melihat bahwa demokrasilah yang mampu menciptakan perdamaian antarnegara, karena di antara negaranegara yang demokratis kecenderungan untuk berperang sangatlah kecil, bahkan tidak ada sama sekali. Konflik yang terjadi di antara negara-negara demokratis bukanlah konflik yang melibatkan senjata, namun kompetisi untuk meraih kepentingan dengan upayaupaya 'damai'.

Kita bisa melihat bahwa gagasan dalam democratic peacetelah memberikan corak pada politik luar negeri Amerika Serikat. Bahkan bisa dikatakan demokratisasi digunakan untuk menjustifikasi politik luar negeri. Sebagaimana pada era Bill Clinton, Clinton mendukung upaya demokratisasi di negaranegara pecahan Yugoslavia pada tahun 1994. Democratic peace juga 
kembali menjadi top issue dalam politik luar negeri Bush. Gagasan dalam democratic peace bahkan digunakan sebagai 'dalil' untuk melegitimasi invasi Amerika ke Afghanistan yang disebut oleh Amerika sebagai sarang teroris, bahkan pre-emptive war melawan negara otoriter seperti Irak. Pada era Obama, gagasan democratic peace memang tidak lagimuncul ke permukaan. Walaupun demikian, kita dapat melihat sentuhan democratic peace memengaruhi intervensi Amerika Serikat untuk mendukung kelompok oposisi di negara yang otoriter, seperti Libya dan Suriah.

Lantas, apakah yang mendrive (mendorong) politik luar negeri Trump? Mungkin slogan Trump selama kampanye "Make Amerika Great Again!” serta term "America First" adalah jawabannya. Dalam bidang keamanan, Trump menempatkan isu terorisme sebagai top priority tanpa begitu memperdulikan konstelasi politik dan posisi Amerika Serikat sebelum pemerintahannya. Walaupun samasama berasal dari Partai Republik seperti halnya Bush, namun kita bisa melihat bahwa gagasan democratic peace nampaknya sudah outdatedsemenjak Trump berkuasa. Agenda perang melawan terorisme di Suriah yang diartikulasikan oleh Trump nampaknya tidak berkaitan dengan isu demokratisasi dan antiotoritarianisme. Trump bahkan semenjak kampanye juga melakukan pendekatan terhadap Rusia. Padahal sejauh ini Rusia yang merupakan rival bagi Amerika Serikat dalam percaturan internasional selama ini mendukung rezim Assad yang otoriter. Amerika juga berupaya untuk melakukan pendekatan terhadap China terkait dengan isu ekonomi dan deterence terhadap Korea Utara. Atau dengan kata lain kerjasama dengan komunis untuk melawan juche-komunis.

Dalam bidang ekonomi, kebijakan America First yang penuh dengan kontroversi dan kritik , bahkan dari dalam negeri, yang meliputi keluarnya Amerika Serikat dari TPP, impor pajak bagi perusahaan Amerika yang beroperasi di luar negeri, termasuk pembatasan arus migran serta ide 'tembok' pembatas antara Amerika Serikat dengan Meksiko, pada dasarnya adalah upaya untuk meningkatkan kesejahteraan ekonomi bagi Amerika Serikat lewat peningkatan pendapatan dan meminimalisir angka pengangguran. Bagaimanapun, kebijakan luar negeri Trump yang 'unpredictable' nampaknya lebih 
banyak dipengaruhi oleh gagasan nasionalismenya, "Make America Great Again!" dibandingkan dengan democratic virtue.

\section{Referensi}

Baylis, J. (2005). International and Global Security in The PostCold War Era. In J. Baylis, \& S. Smith, The Globalization of World Politics: an Introduction to International Relations (pp. 297-324). New York: Oxford University Press.

Chakraborty, B. (2017, March 06). Trump signs new immigration order, narrows scope of travel ban. Retrieved May 04, 2017, from Fox News: http://www.foxnews.com/ politics/2017/03/06/trumpsigns-new-immigration-ordernarrows-scope-travel-ban.html Cole, J. (2008). "US-Iraq War" Microsoft Encarta 2009. Redmond: Microsoft Corporation.

Doyle, M. (1986). Liberalism and World Politics. The American Political Science Review, 11511169.

Dumas, E. C. (2009). "Bill Clinton" Microsoft Encarta. Redmond: Microsoft Corporation.
Dunne, T. (2005). Liberalism. In J. Baylis, \& S. Smith, The Globalization of World Politcs: an Introduction to International Relations (pp. 185-203). New York: Oxford University Press.

Gaouette, N., \& Kosinski, M. (2017, February 23). Mexico slams US immigration plan as Tillerson arrives. Retrieved May 18, 2017, from http://edition. cnn.com/2017/02/22/politics/ tillerson-kelly-trip-to-mexico/ Ish-Shalom, P. (2013). Democratic Peace: A Political Biography. United States of America: University of Michigan Press.

Needham, V. (2016, July 24). Trump suggests leaving WTO over import tax proposal. Retrieved May 19, 2017, from http://thehill.com/policy/ finance/ 289005 - trump suggests-leaving-wto-overimport-tax-proposal

Politico Staff. (2016, August 15). Full text: Donald Trump's speech on fighting terrorism. Retrieved May 17, 2017, from http://www. politico.com/story/2016/08/ donald-trump-terrorismspeech-227025

Pugh, J. (2005, April). Democratic Peace Theory: A Review and Evaluation. Retrieved May 15, 
2017, from Center for Mediation, Peace, and Resolution of Conflict, International: https://www.cemproc.org/ democraticpeaceCWPS.pdf

Richardson, J. L. (2012). Liberalism.

In R. Devetak, A. Burke, \&

J. George, Introduction to International Relations (pp. 48-60). New York: Cambridge University Press.

Wąsiński, M. (2017). Donald Trump's Foreign Policy Stances: Unpredictability and Neoisolationism. Retrieved May 04, 2017, from Australian Institute of International Affairs: http:// www.internationalaffairs. org.au/global-wire/donaldtrumps-foreign-policy-stancesunpredictability-and-neoisolationism/
White House. (2017). America First Foreign Policy. Retrieved May 04, 2017, from White House: https://www.whitehouse.gov/ america-first-foreign-policy 